\title{
Short communication: Genetic and environmental relationships between milk yield and kidding interval in dairy goats
}

\author{
H. H. Montaldo, ${ }^{* 1}$ M. Valencia-Posadas, † G. R. Wiggans,‡ L. Shepard,§ and J. A. Torres-Vázquez\# \\ *Departamento de Genética y Bioestadística, Facultad de Medicina Veterinaria y Zootecnia, Universidad Nacional Autónoma de México, \\ Ciudad Universitaria, D.F. 04510, Mexico \\ †División de Ciencias de la Vida, Campus Irapuato-Salamanca, Universidad de Guanajuato, ExHacienda El Copal, Irapuato, Guanajuato 36500, \\ Mexico \\ $\ddagger$ Animal Improvement Programs Laboratory, Agricultural Research Service, USDA, Beltsville, MD 20705-2350 \\ §American Dairy Goat Association, Spindale, NC 28160 \\ \#Centro Nacional de Investigación en Fisiología y Mejoramiento Animal, Instituto Nacional de Investigaciones Forestales, Agrícolas y Pecuarias, \\ Secretaría de Agricultura, Ganadería, Desarrollo Rural, Pesca y Alimentación, Ajuchitlán, Querétaro 76280, Mexico
}

\begin{abstract}
First-parity 305-d milk yield and intervals between first and second kiddings from 1975 through 2005 were analyzed to estimate genetic and environmental parameters for United States Alpine, LaMancha, Nubian, Saanen, and Toggenburg dairy goats. The data set included 43,612 does with first-parity milk yield and 25,863 does with first kidding interval. Parameters were estimated by REML using bivariate mixed models within and across breeds. Fixed effects were month and herd-year of kidding within breed and month and breedherd-year of kidding across breeds. Random effects were animal and residual. The heritability estimate for first-parity milk yield was $0.36 \pm 0.01$ across breeds and ranged from 0.35 to 0.38 within breed; heritability for first kidding interval was $0.05 \pm 0.01$ across breeds and ranged from 0.00 to 0.15 within breed. The estimate of the genetic correlation between firstparity milk yield and first kidding interval was positive (unfavorable) across breeds $(0.35 \pm 0.09)$. Estimates of environmental correlations within and across breeds were positive (0.16-0.25). The presence of unfavorable genetic relationships between milk yield and kidding interval indicates a need to include reproductive performance as a selection criterion.
\end{abstract}

Key words: genetic parameter, kidding interval, milk yield, dairy goat

Several studies (e.g., Pryce et al., 2004; AndersenRanberg et al., 2005) have indicated unfavorable genetic and environmental correlations between milk yield and fertility in dairy cattle. Because of the economic importance of fertility, reproduction traits have been incorporated as a selection criterion for dairy cattle in

Received July 27, 2009.

Accepted September 30, 2009.

${ }^{1}$ Corresponding author: montaldo@servidor.unam.mx many countries (e.g., VanRaden, 2004). Knowledge of those relationships in dairy goats is limited. Estimates of heritabilities and correlations are needed (Montaldo and Manfredi, 2002). The objective of this study was to estimate heritabilities of milk yield and kidding interval for 5 goat breeds based on first kiddings as well as genetic, environmental, and phenotypic correlations between those traits.

Milk yield and kidding interval data from DHI lactation records in the USDA national dairy database (Beltsville, MD) and provided to the American Dairy Goat Association (Spindale, NC) were analyzed for kiddings between 1975 and 2005. Pedigree information was available for all does with records and their ancestors for animals born in 1971 or later. First-parity, matureequivalent, 305-d milk yield (Wiggans and Hubbard, 2001), and interval between first and second kiddings were analyzed. Only data from lactations with $\geq 100$ DIM and from herd-year-breed combinations and sires with $\geq 2$ daughter records were retained for final analysis. Records with first kidding intervals of $<170$ or $>730 \mathrm{~d}$ were considered to be abnormal and were excluded. Numbers of sires and does for first-parity milk yield and first kidding interval are shown in Table 1 along with means (unadjusted) and phenotypic SD (unadjusted and from the analysis).

Data were analyzed within breed (Alpine, LaMancha, Nubian, Saanen, and Toggenburg) with bivariate mixed models that included fixed effects for month and herdyear of kidding. Random effects were animal (with all relationships considered through the inverse of the numerator relationship matrix) and residual. Covariance components were estimated with ASReml (Gilmour et al., 2006). All breeds also were analyzed together by including a breed-herd-year instead of herd-year effect in the model.

Heritability estimates for first-parity milk yield (Table 2) were large $(0.35-0.38)$ compared with previous estimates (Montaldo and Manfredi, 2002; Valencia et 
Table 1. Numbers of sires and does, means (unadjusted), and phenotypic SD (unadjusted and from model analysis) for first-parity milk yield and interval between first and second kiddings of United States dairy goats by breed

\begin{tabular}{lrrrrrr}
\hline Item & Alpine & LaMancha & Nubian & Saanen & Toggenburg & All breeds \\
\hline Sires, n & 2,346 & 994 & 2,544 & 1,123 & 1,036 & 8,043 \\
First-parity milk yield & & & & & & \\
$\quad$ Does, n & 15,147 & 4,633 & 12,227 & 5,828 & 5,777 & 43,612 \\
$\quad$ Mean, kg & 1,090 & 978 & 928 & 1,187 & 1,050 & 1,040 \\
$\quad$ Phenotypic SD, kg & 322 & 290 & 303 & 392 & 317 & 379 \\
$\quad$ Unadjusted & 245 & 216 & 210 & 278 & 235 & 237 \\
$\quad$ From model analysis & & & & & & \\
First kidding interval & 9,222 & 2,623 & 7,075 & 3,451 & 3,492 & 25,863 \\
$\quad$ Does, n & 381 & 374 & 373 & 384 & 382 & 379 \\
$\quad$ Mean, d & & & & & & 89 \\
$\quad$ Phenotypic SD, d & 89 & 90 & 87 & 93 & 79 & 79 \\
$\quad$ Unadjusted & 82 & 82 & 75 & 77 & & 78 \\
$\quad$ From model analysis & & & & & & \\
\hline
\end{tabular}

al., 2007; Torres-Vázquez et al., 2009), which shows the possibility for increased accuracy of selection and more rapid genetic improvement for productivity (Montaldo et al., 1994). The heritability estimate for first-parity milk yield from the analysis across breeds was $0.36 \pm$ 0.01 .

Heritability estimates for first kidding interval (Table 2 ) ranged from 0.00 to 0.15 . The heritability estimate of 0.00 for Nubians may be the result of sampling error; larger data sets may be needed to estimate genetic parameters accurately for first kidding interval. The across-breed heritability estimate for first kidding interval was $0.05 \pm 0.01$, which was slightly larger than the estimates of 0.02 for Polish goats and 0.03 for Norwegian goats reported by Bagnicka et al. (2007). Breed variation in heritability estimates for first kidding interval may be caused by low heritability for all breeds and large sampling variances, as shown by the relatively large standard errors (Table 2). Previous heritability estimates for kidding interval from small samples (Odubote, 1996; Ribeiro et al., 2000; Lôbo and da Silva, 2005) probably had large standard errors; however, those estimates ranged from 0.01 to 0.09 , which indicated that heritability is less than 0.10 .
Estimates of genetic correlation between first-parity milk yield and first kidding interval (Table 2) were positive (unfavorable) for Alpines (0.31), LaManchas (0.36), Saanens (0.26), and Toggenburgs (0.38). A likelihood ratio test (Gilmour et al., 2006) indicated that the genetic correlation was different from zero for Alpines $(P<0.01)$ and LaManchas $(P<0.05)$ but not for Saanens or Toggenburgs $(P>0.05)$. The genetic correlation was not estimable for Nubians because the heritability estimate for first kidding interval was near zero. The across-breed genetic correlation (0.35) based on data from all breeds also was different from zero $(P<0.01)$. The low heritability estimates for first kidding interval compared with first-parity milk yield and positive genetic correlations between first kidding interval and first-parity milk yield agree with reports for reproductive traits of dairy cattle (Castillo-Juarez et al., 2000; Pryce et al., 2004; Andersen-Ranberg et al., 2005). VanRaden et al. (2004) estimated the genetic correlation between days open and milk yield to be 0.38 for United States Holsteins. Because of the positive genetic correlation between first-parity milk yield and first kidding interval, selection indexes should include first kidding interval to prevent a decline in fertility.

Table 2. Estimates of heritability and genetic, environmental, and phenotypic correlations for first-parity milk yield and interval between first and second kiddings of United States dairy goats by breed

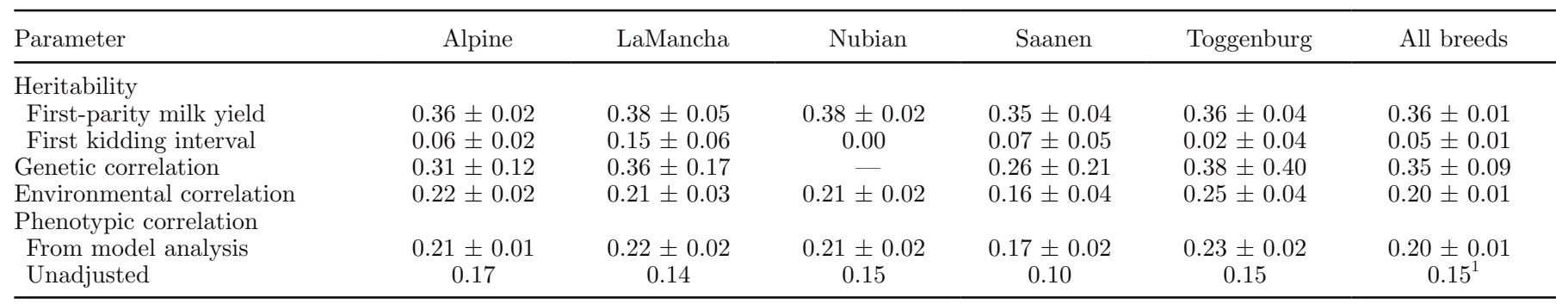

${ }^{1}$ Weighted mean across breeds. 
Estimates of the environmental correlations between first-parity milk yield and first kidding interval (Table 2) were positive (unfavorable) for all breeds (0.160.25 ), with small standard errors. The across-breed environmental correlation was 0.20 . Because of the small heritability estimates for first kidding interval, phenotypic correlations (Table 2) were determined almost completely by environmental correlations. Similar estimates have been reported for dairy cattle (Pryce et al., 2004; Andersen-Ranberg et al., 2005; Mackey et al., 2007). Unadjusted phenotypic correlations between milk yield and kidding interval, which include the covariances across herd-years (Table 2), were also positive, but they were smaller than phenotypic correlations from model residuals. The environmental correlations indicate some environmental antagonism between milk yield and fertility within herd-year. However, the unadjusted phenotypic correlations, which include herd-year effects, were smaller than environmental correlations, indicating favorable management effects across herdyears for both traits.

\section{ACKNOWLEDGMENTS}

The authors thank S. M. Hubbard (Animal Improvement Programs Laboratory, Agricultural Research Service, USDA, Beltsville, MD) for suggestions on manuscript improvement.

\section{REFERENCES}

Andersen-Ranberg, I. M., G. Klemetsdal, B. Heringstad, and T. Steine. 2005. Heritabilities, genetic correlations, and genetic change for female fertility and protein yield in Norwegian dairy cattle. J. Dairy Sci. 88:348-355.

Bagnicka, E., E. Wallin, M. Łukaszewicz, and T. Ádnøy. 2007. Heritability for reproduction traits in Polish and Norwegian populations of dairy goat. Small Rumin. Res. 68:256-262.

Castillo-Juarez, H., P. A. Oltenacu, R. W. Blake, C. E. McCulloch, and E. G. Cienfuegos-Rivas. 2000. Effect of herd environment on the genetic and phenotypic relationships among milk yield, conception rate, and somatic cell score in Holstein cattle. J. Dairy Sci. 83:807-814.

Gilmour, A. R., B. R. Cullis, S. J. Welham, and R. Thompson. 2006. ASReml User Guide. Release 2.0. VSN International Ltd., Hemel Hempstead, UK.

Lôbo, R. N. B., and F. L. R. da Silva. 2005. Parâmetros genéticos para características de interesse econômico em cabras das raças Saanen e Anglo-nubiana. [Genetic parameters for economics traits in Saanen and Anglo-Nubian goats.] Revista Ciência Agronômica 36:104-110.

Mackey, D. R., A. W. Gordon, M. A. McCoy, M. Verner, and C S. Mayne. 2007. Associations between genetic merit for milk production and animal parameters and the fertility performance of dairy cows. Animal 1:29-43.

Montaldo, H. H., and E. Manfredi. 2002. Organisation of selection programmes for dairy goats. Commun. no. 01-35 in Proc. 7th World Congr. Genet. Appl. Livest. Prod., Montpellier, France. INRA, Paris, France.

Montaldo, H. H., M. Valencia-Posadas, and F. Sánchez. 1994. Respuesta esperada a la selección para producción de leche en caprinos con pruebas de progenie, MOET y selección masal. [Expected genetic response for milk production in goats with progeny testing, MOET and mass selection.] Arch. Zootec. 43:335-343.

Odubote, I. K. 1996. Genetic parameters for litter size at birth and kidding interval in the West African Dwarf goats. Small Rumin. Res. 20:261-265.

Pryce, J. E., M. D. Royal, P. C. Garnsworthy, and I. L. Mao. 2004 Fertility in the high-producing dairy cow. Livest. Prod. Sci. $86: 125-135$

Ribeiro, A. C., J. F. Lui, S. A. Queiroz, S. D. A. Ribeiro, and K. T. Resende. 2000. Genetic and environmental effects on the age at first kidding and kidding interval in a Saanen goat herd. Ars Vet. 16:192-197.

Torres-Vázquez, J. A., M. Valencia-Posadas, H. Castillo-Juárez, and H. H. Montaldo. 2009. Genetic and phenotypic parameters of milk yield, milk composition and age at first kidding in Saanen goats from Mexico. Livest. Sci. 126:147-153.

Valencia, M., J. Dobler, and H. H. Montaldo. 2007. Genetic and phenotypic parameters for lactation traits in a flock of Saanen goats in Mexico. Small Rumin. Res. 68:318-322.

VanRaden, P. M. 2004. Invited review: Selection on net merit to improve lifetime profit. J. Dairy Sci. 87:3125-3131.

VanRaden, P. M., A. H. Sanders, M. E. Tooker, R. H. Miller, H. D. Norman, M. T. Kuhn, and G. R. Wiggans. 2004. Development of a national genetic evaluation for cow fertility. J. Dairy Sci $87: 2285-2292$

Wiggans, G. R., and S. M. Hubbard. 2001. Genetic evaluation of yield and type traits of dairy goats in the United States. J. Dairy Sci 84(E-Suppl.):E69-E73. 